\title{
Quality of life after liver transplantation
}

\author{
David Grant, MD, FRCSC, David Evans, PhD, Margaret Hearn, PHD, \\ JOHN DUFF, MD, FRCSC, FACS, CAMERON GHENT, MD, FRCPC, WILLIAM WALL, MD, FRCSC
}

ABSTRACT: The results of liver transplantation are now well established in terms of graft and patient survival, but there is surprisingly little data on the quality of life attained. The authors mailed questionnaires to 32 consecutive adult liver recipients to assess their quality of life. Thirty-one patients ( 14 males, 17 females) with a mean age of 37 years (range 16 to 55 ), responded (97\%). The mean time since transplantation was 19 months (range three to 50). Eighty per cent $\mathrm{c}$ the respondents functioned at normal or near normal levels as measured by the Karnofsky Performance Index. Sixty-five per cent ( 20 patients) indicated they were currently able to live and function as they did before they became ill with liver disease. The respondents' scores were similar to normative scores on all of the following measures: life satisfaction, well being, and general affect (Campbell); and material well being, personal growth, marital relations, family relations and friendships (Evans). It is concluded that liver transplantation restores physical, mental and social well being in most patients with endstage liver disease. Can J Gastroenterol 1990;4(2):49-52

Key Words: Life style, Liver transplantation, Quality of life

\section{La qualité de vie après la transplantation hépatique}

RESUME: Les résultats de la transplantation hépatique sont maintenant bien établis en termes de greffe et de survie du patient, mais il existe étonnamment peu de données quant à la qualité de vie qui en résulte. Les auteurs ont envoyé à 32 receveurs adultes consécutifs des questionnaires destinés à évaluer la qualité de leur vie. Trente-et-un patients ( 14 hommes, 17 femmes) âgés de 37 ans en moyenne (16 à 55 ans) ont répondu (97\%). Le temps écoulé depuis l'intervention était en moyenne de 19 mois ( 3 à 50 mois). Quatre-vingts pour cent des répondants vivaient à un niveau normal, ou à peu près normal, selon l'indice de Performance de Karnofsky. Soixante-cinq pour cent d'entre eux (20 patients) ont déclaré être en mesure de vivre et de fonctionner comme avant d'être

Departments of Surgery, Medicine, and Psychology, University of Western Ontario, London, Ontario

Correspondence and reprints: Dr David Grant, University Hospital, PO Box 5339, Postal

Station A, London, Ontario N6A 5A5. Telephone (519) 663-2926

Received for publication May 10, 1989. Accepted January 9, 1990.
$\mathrm{T}$ HE PAST DECADE HAS WITNESSED significant progress in liver transplantation. One year patient survival rates have increased to $70 \%$ or more as a result of improved selection of transplant candidates, better immunosuppression with cyclosporine, and careful perioperative patient management $(1,2)$. Moreover, patients who survive the first year after liver transplantation have an excellent chance of living for many years. Reports from Pittsburgh indicate that annual long term mortality rates in patients who survive the first year after transplantation are now less than $3 \%$ (3).

The improved results with liver grafting have stimulated a dramatic growth in the number of transplants performed throughout the world. The proliferation of liver transplant programs and the associated ethical, social and financial implications have led to legitimate concerns about the costs and benefits of this procedure. To date, however, most evaluations of liver transplantation have focused on graft and patient survival rates. There are surprisingly few data on the health of liver recipients (4-8). The present study was therefore undertaken to measure the degree of rehabilitation and the quality of life after liver grafting at the authors' institution. 
atteints de maladie hépatique. Les scores obtenus étaient similaires à la norme pour toutes les mesures suivantes: satisfaction envers la vie, bien-être, et état affectif général (Campbell); bien-être matériel, croissance personnelle, relations maritales, relations de famille et amitiés (Evans). Nous concluons que la transplantation hépatique permet à la plupart des patients atteints de maladie hépatique permet à la plupart des patients atteints de maladie hépatique terminale de retrouver le bien-être physique, mental et social.
Measures: Confidential questionnaires were mailed to 32 consecutive patients who had undergone orthotopic liver transplants at University Hospital, London, Ontario. Participants comcluded demographic information, data required for the Karnofsky Index (9), the Work/Employment Scale (10), and the details of post transplant medical care. The respondents also completed paper-and-pencil versions of Campbell's Life Appraisal questions and Life Satisfaction questions (11); and Evans' material well being, personal growth, marital relations, extended family relations, extrafamilial relations, and social desirability scales $(12,13)$. To avoid expectation bias, the information sheet accompanying the questionnaires stressed the fact that physicians and nurses providing ongoing patient care would not be privy to individual responses. The study was approved by the University of Western Ontario Health Sciences Standing Committee on Research Involving Human Subjects.

Analysis: SPSS-X (release 2.2) was used on a DECVAX-11/780 VMS computer to calculate the range, arithmetic means, standard deviations, and intercorrelations. Responses were compared to previously established normative data. The quality of life measures were analyzed by a principal component factor analysis, followed by an oblique rotation of factors meeting the Kaiser criterion, with delta set at 1.0.

\section{RESULTS}

Respondents: Thirty-one patients (97\%) completed the questionnaire, including 14 males and 17 females with a mean age of 37.9 years (range 16 to 55). The distribution of the participants' demographic profile was similar to the

\section{PATIENTS AND METHODS} pleted an information sheet that in-
Canadian population (Table 1). Primary biliary cirrhosis (45\%) and chronic active hepatitis (19\%) were the most common indications for transplantation. Twenty-five participants $(80.7 \%)$ had one transplant, five $(16.1 \%)$ had two transplants, and one $(3.2 \%)$ had three transplants. All of the respondents were maintained on cyclosporine, and the majority (94\%) were also on prednisone. The mean time since transplantation was 19.3 months (range 3.4 to 48.5 ).

Rehabilitation: The respondents reported the following rates of medical care per week: none $58 \%, 1 \mathrm{~h}$ or less $26 \%$, and more than $1 \mathrm{~h} 16 \%$. Three patients $(10 \%)$ reported major concerns about rejection. Nearly $80 \%$ ( 22 patients) reported normal or near normal activity levels as measured by the Karnofsky Performance Index (Table $2)$. Ninety per cent (28 patients) had returned to their previous activities as wage earners ( 20 patients), household managers (six patients) or students (two patients). Sixty-five per cent (20 patients) indicated they were currently able to live and function as they did before they became ill with liver disease.

Quality of life: When asked how satisfied they were with their lives as a whole, $77.5 \%$ (24 patients) were very

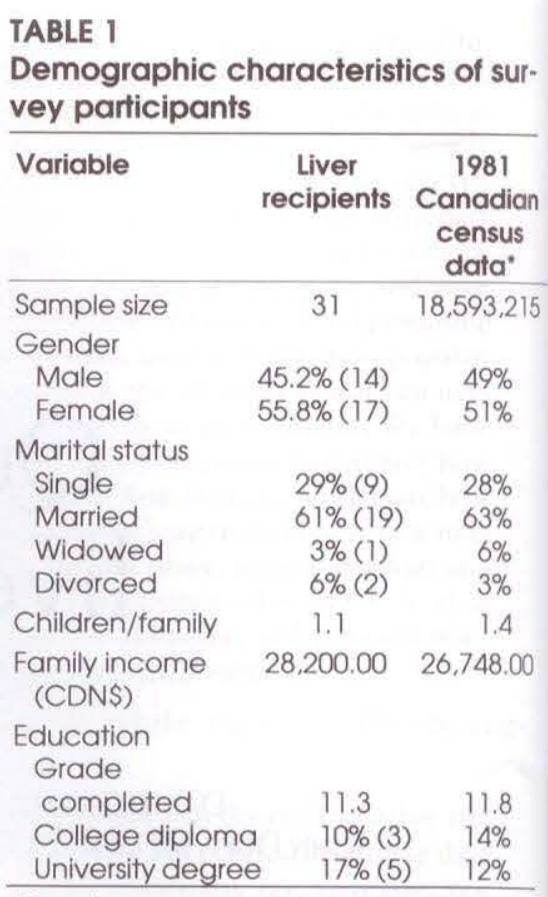

- Based upon census data for age 15 years or greater

satisfied, $6.5 \%$ were marginally satisfied (two patients), and $16 \%$ (five patients) were dissatisfied. There were no sig. nificant differences between the responses of the liver recipients and the normative samples as shown in Table 3. The liver recipients' responses were no more contaminated than the normative samples with socially desirable responses.

Further statistical analysis demonstrated significant intercorrelations between the quality of life measures, indicating multidimensional relationships between the respective variables (data not shown). The structure matrix of two factors derived by factor analysis is shown in Table 4. Factor I, which

\section{TABLE 2}

\section{Functional ability of liver recipients on the Karnofsky Activity Index}

\begin{tabular}{lc}
\hline Category & Number of liver recipients \\
\hline No complaints, almost normal physical activity & $13(46.4 \%)$ \\
Able to carry out normal activity with effort & $9(32.1 \%)$ \\
$\begin{array}{l}\text { Able to care for myself but unable to carry out normal } \\
\text { activity }\end{array}$ & $4(14.3 \%)$ \\
$\begin{array}{l}\text { Require occasional assistance, but am able to carry } \\
\text { out most self care }\end{array}$ & $2(7.1 \%)$ \\
$\begin{array}{l}\text { Require considerable assistance and frequent } \\
\text { medical care }\end{array}$ & $0(0.0 \%)$ \\
Nonrespondents & 3 \\
\hline
\end{tabular}


TABLE 3

Scores of liver transplant patients on the quality of life scales

\begin{tabular}{lccc}
\hline Measure & Scale & $\begin{array}{c}\text { Scores of liver } \\
\text { recipients }\end{array}$ & $\begin{array}{c}\text { Normative } \\
\text { sample }\end{array}$ \\
\hline Well being & $2-14$ & 11.44 & $11.77^{*}$ \\
Psychological affect & $1-7$ & 5.55 & $5.68^{*}$ \\
Life satisfaction & $1-7$ & 5.36 & $5.55^{*}$ \\
Material well being & $1-12$ & 8.45 & $9.55^{\dagger}$ \\
Personal growth & $1-12$ & 8.29 & $8.46^{\dagger}$ \\
Marital relations & $1-12$ & 9.25 & $8.64^{\dagger}$ \\
Extended family relations & $1-12$ & 8.13 & $7.99^{\dagger}$ \\
Extrafamilial relations & $1-12$ & 8.26 & $7.71^{\dagger}$ \\
Social desirability & $1-12$ & 6.97 & $7.65^{\dagger}$ \\
\hline
\end{tabular}

- From Campbell et al (11): From Evans et al (13)
TABLE 4

Factor analysis of the quality of life measures in liver recipients

\begin{tabular}{lcc}
\hline & Factor I & Factor II \\
\hline $\begin{array}{l}\text { Extrafamilial } \\
\text { relations }\end{array}$ & 0.84 & \\
$\begin{array}{l}\text { Extended family } \\
\text { relations }\end{array}$ & 0.77 & \\
Well being & 0.75 & 0.74 \\
Marital relations & 0.56 & \\
Material well being & 0.54 & 0.47 \\
Personal growth & 0.62 & 0.80 \\
Ability to function & 0.77 & \\
Common variance & $44.7 \%$ & $16.4 \%$ \\
\hline
\end{tabular}

a prior history of psychiatric problems; the importance of family support; the value of perioperative educational programs; the frequency and severity of adverse drug reactions, particularly those due to cyclosporine, prednisone, or antihypertensive medications; and finally, the frequency of residual neuropsychiatric damage secondary to longstanding hepatic encephalopathy. analysis of these data revealed two principal areas contributing to the quality of life after liver transplantation: the quality of extrafamilial and extended family relationships; and the ability to carry out normal activities (Table 4). Both of these factors were associated with a sense of personal and general well being. These data support the clinical impression that liver recipients often have a renewed appreciation for friends, family, and daily routine.

Liver transplantation was not always successful. Twenty per cent of the respondents in this survey were not fully rehabilitated and/or reported a poor quality of life. Thirty-five per cent of the respondents were unable to live and function as they did before they had liver disease. These patients present a major challenge for planners and providers of liver transplantation.

Quality of life may continue to improve for years after liver transplantation. The mean follow-up in the present study was only 19.3 months. Longitudinal studies with diseasespecific quality of life measures would help to identify more accurately factors affecting patient health after liver transplantation $(17,18)$. Issues that merit further study include the effect of
ACKNOWLEDGEMENTS: The contributions of Margaret Sherlock and Jeanette Mikulic are gratefully acknowledged. David Grant is a Career Scientist, with the Ontario Ministry of Health.

\section{REFERENCES}

1. Wall WJ, Grant D, Duff J, Kutt JL, Ghent C, Bloch M. Liver transplantation without venous bypass. Transplantation 1987;43:56-61.

2. Wall WJ. Liver transplantation: Current concepts. Can Med Assoc J 1988;139:21-8.

3. Iwatsuki S, Starzl TE, Gordon RD, et al. Late mortality and morbidity after liver transplantation. Transplant Proc 1987;19:2373-7.

4. Starzl TE, Koep J, Schroter J, et al. The quality of life after liver transplantation. Transplant Proc 1979;11:252-6.

5. MacDougall BRD, McMaster P, Calne RY, Williams R. Survival and rehabilitation after orthotopic liver transplantation. Lancet 1980;i:1326-8.

6. Tarter RE, Erb S, Biller PA, Switala J, Van Thiel DH. The quality of life following liver transplantation: A preliminary report. Gastroenterol Clin North Am 1988;17:207-17.

7. Colonna JO, Brems JJ, Hiatt JR, et al. The quality of survival after liver 
transplantation. Transplant Proc 1988;20:594-7.

8. Gutkind L. Life after transplantation. Transplant Proc 1988;20:1092-9.

9. Karnofsky DA, Abelmann WH, Craver LF, Burchenal JH. The use of nitrogen mustard in the palliative treatment of carcinoma. Cancer 1948;634-56.

10. Evans RW, Mannine DL, Garrison LP, et al. The quality of life of patients with end-stage renal disease. $\mathrm{N}$ Engl J Med 1985;312:553-9.

11. Cambell A, Converse PE, Rodgers WL. The Quality of American Life: Perceptions, Evaluations and Satisfactions. New York: Russel Sage, 1976.
12. Evans DR, Robinson WE. Manual for the quality of life questionnaire.

Toronto: Multi-Health Systems, 1989.

13. Evans DR, Burns JE, Robinson WE, Garrett OJ. The quality of life questionnaire: A multidimensional measure.

Am J Community Psychol 1985;13:305-22.

14. Van Thiel DH, Tarter R, Gavaler JS, Potanko WM, Schade RR. Liver transplantation in adults. An analysis of costs and benefits at the University of Pittsburgh. Gastroenterology 1986;90:211-6.

15. Breslow L. A quantitative approach to the World Health Organization definition of health: Physical, mental and social well being. Int J Epidemiol 1972;1:347-55.

16. Aaronson NK, Beckman JH, eds. Quality of Life in Cancer

Patients. New York: Raven Press, 1987.

17. Guyatt GH, Bombardier C, Tugwell PX. Measuring disease-specific quality of life in clinical trials. Can Med Assoc J 1986;134:889-95.

18. Sackett DL, Chambers LW, MacPherson AS, Goldsmith CH, McAuley RG. The development and application of indices of health: General methods and a summary of results. Am J Public Health 1977;67:423-8. 


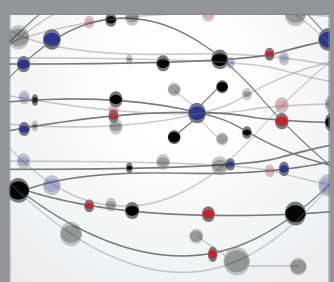

The Scientific World Journal
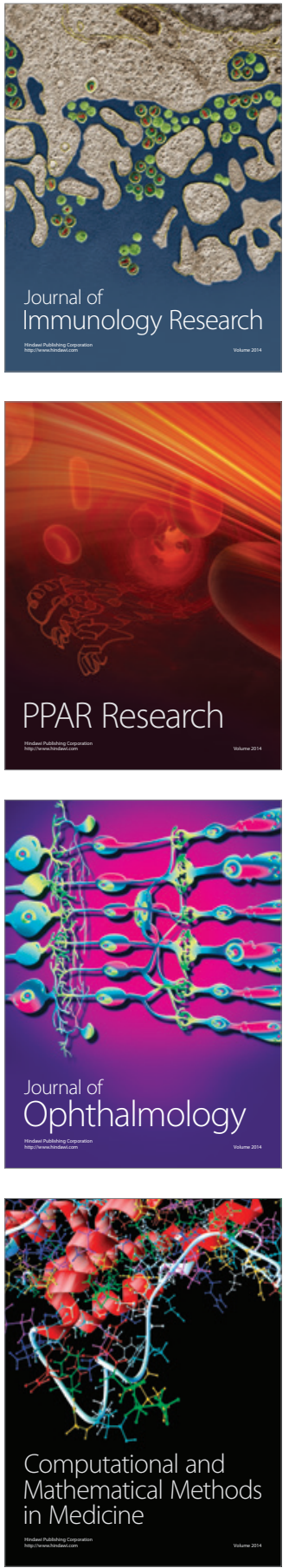

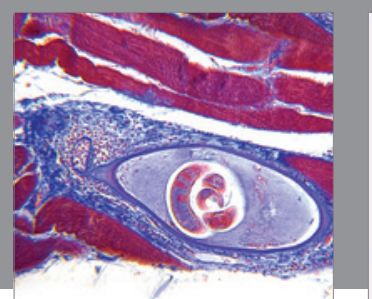

Gastroenterology Research and Practice

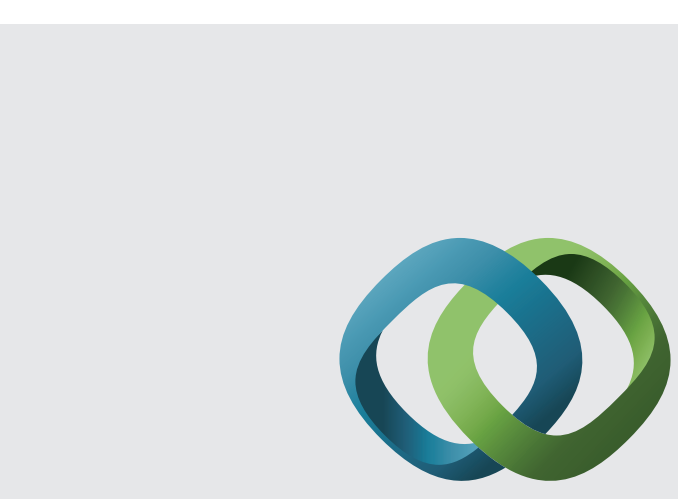

\section{Hindawi}

Submit your manuscripts at

http://www.hindawi.com
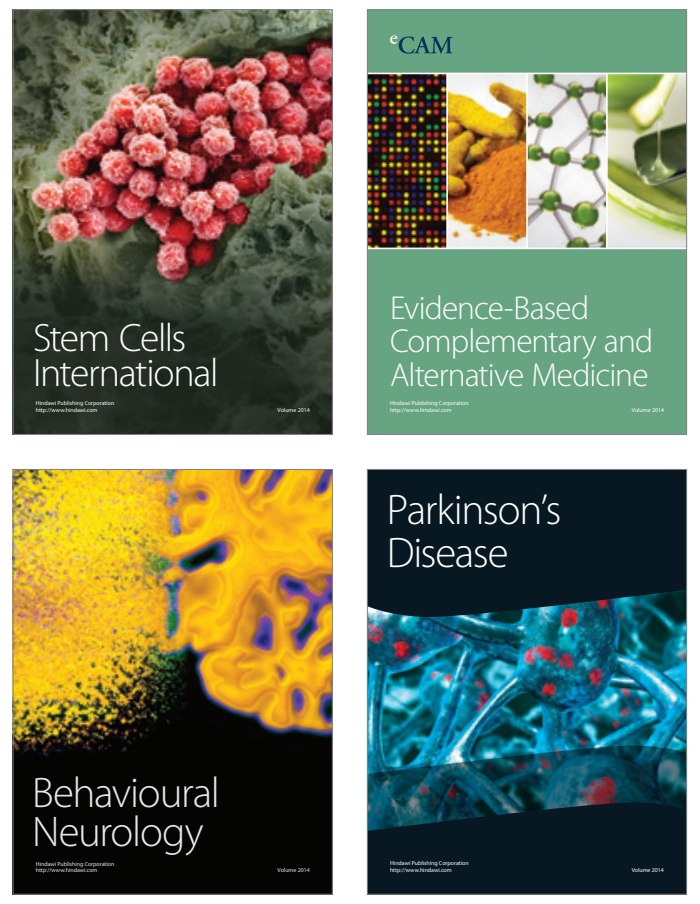
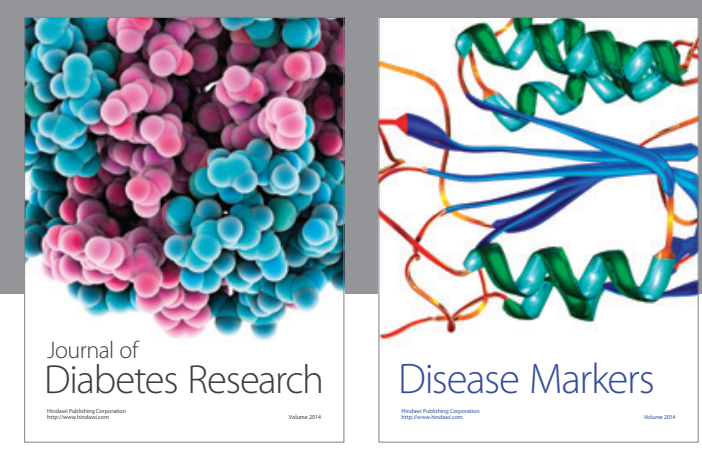

Disease Markers
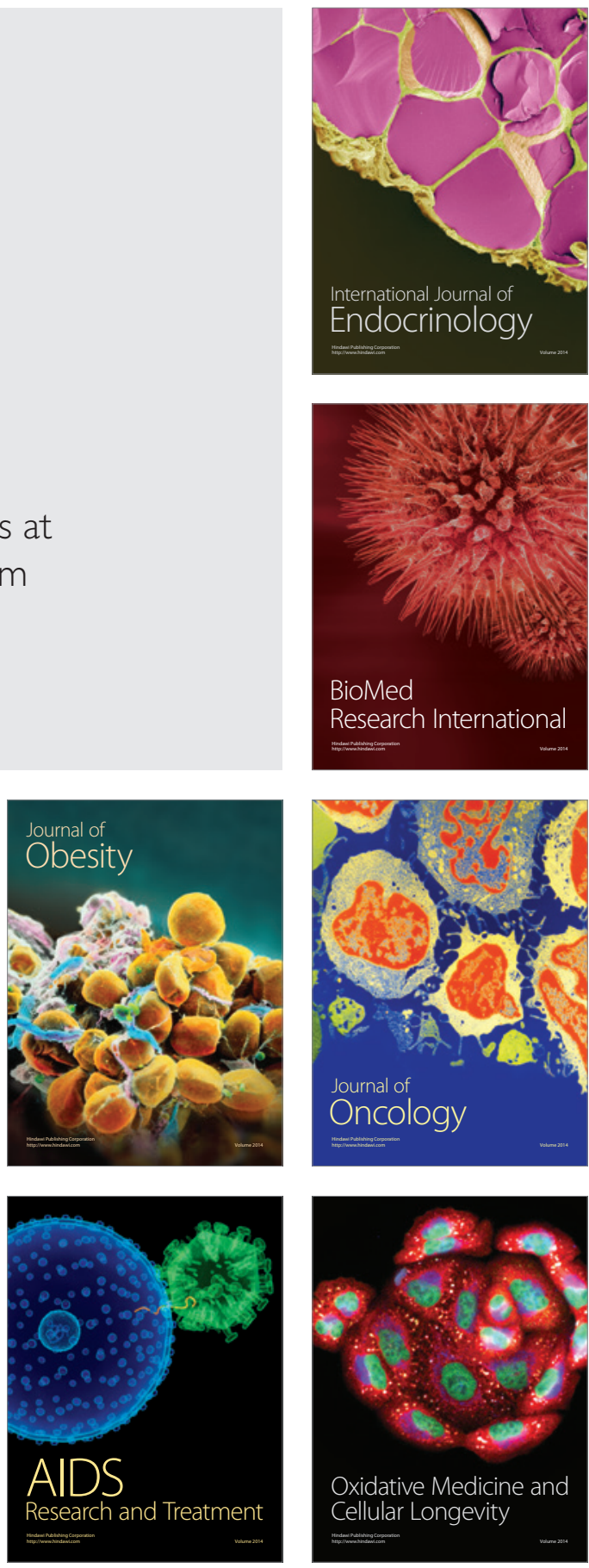